\title{
The Potential Of Dki Jakarta Tourism Object Development Case Study In Pancasila Sakti Monument In Lubang Buaya Jakarta
}

\author{
Nur Fitri Rahmawati ${ }^{1}$, Anita Maulina ${ }^{2}$, Bisma Widyawan ${ }^{3}$, Trie Andari Ratna Widyastuti ${ }^{4}$ \\ 1234The STIAMI Insitute of Social Sciences and Management \\ Correspondent: fitri.alfaruq@gmail.com
}

Submitted : September 25, 2020 Revised : October 17, 2020 Published : October 31, 2020

\begin{abstract}
The Pancasila Sakti Monument in Lubang Buaya, Jakarta is one of the tourism identities of DKI Jakarta, many efforts have been made in developing the preservation and preserving the cultural assets that are still left in the Pancasila Sakti Monument in Lubang Buaya. The purpose of this research is to determine the potential development of tourism objects in Pancasila Sakti Monument in Lubang Buaya by analyzing the historical values and uniqueness. This study used a descriptive qualitative method that describes the information of the Tourism Object from Pancasila Sakti Monument in Lubang Buaya. Data collection techniques used were interviews, literature study, observation and documentation. The data collection was analyzed and grouped based on the research problems. The results of this study indicate that the Tourism Object namely Pancasila Sakti Monument in Lubang Buaya is one of the tourism objects that has potential to be developed in DKI Jakarta.
\end{abstract}

Keywords: pancasila sakti monument, lubang buaya, tourist attraction, potential, development

\section{INTRODUCTION}

As a rich country with the natural beauty, cultural diversity and arts, Indonesia can actually increase its country's income through tourism. In line with the tourism development in Indonesia, efforts have been made to display things that can increase foreign exchange, including bringing in the tourists.

The efforts that can bring in tourists are including maintain the authenticity of the renovated buildings and promote the tourism objects as tourist attractions. Tourism is an industry that is expected to increase in areas economic growth, so the tourist destinations or countries visited by many tourists.

In short, traveling is a process of temporarily journey of one or more people to another place outside their residence. Encouragement to have journey is due to the various interests, whether economic, social, cultural, political, religious, health or other interests such as curiosity, gaining experience, or being able to encourage and increase the local activities development, such as open new business, open jobs, increase the community and local income if they are managed and developed optimally.

Apart from being the capital city of the Republic of Indonesia, Jakarta is also a tourist destination for local people, people from outside Jakarta and abroad. Jakarta must be able to increase tourism visitors, so that the capital city is not only impressed as a city that is jammed and densely populated, but also the existence of enhanced tourism objects. It will bring the good image of Jakarta and have other positive impacts. Jakarta has many potential tourism assets to be developed which will have a positive impact on regional economic activities. 
The Potential Of Dki Jakarta Tourism Object Development Case Study In Pancasila Sakti Monument In Lubang Buaya Jakarta

Rahmawati, Maulina, Widyawan, \& Widyastuti

One of the cultural and historical heritages in Jakarta is the Pancasila Sakti Monument in Lubang Buaya. Based on the researcher's observations, the developments of the Pancasila Sakti Monument in Lubang Buaya as the tourism object that has been carried out in an integrated manner across its sectors and regions and also actively involves the business world and community groups. But the implementation is not optimal, it is proof from the lack of visitors in certain months and it can be seen that the public does not fully understand about the tourism object such as Pancasila Sakti Monument in Lubang Buaya, both for local and also foreign.

In order to realize about the vision and mission of the Pancasila Sakti Monument in Lubang Buaya, every individual and also community has the right to actively participate and give their aspirations for the progress and acceleration for this monument.

Marketing is a series of activities, establishments and processes for creating, communicating, delivering, and exchanging offers that have value for consumers, clients, partners and society at large. In line with the new definition of The American Marketing Association (AMA): "Marketing is the activity, set of institutions, and processes for creating, communicating, delivering, and exchanging offerings that have value for customers, clients, partners and society at large".

According to Lancester \& Lester (2011) in M. Liga Suryadana \& Vanny Octavia (2015: 1) Marketing is one of the main activities that need to be carried out by companies, whether they are goods companies or business, in an effort to maintain their business survival. This is due to the fact that marketing is one of the company activities, which is directly related to consumers. The meaning of marketing depends on whatever the user wants to mean because there are no universally agreed about the definitions and over the years it has been the subject of much research.

According to Kotler and Keller (2012: 25), who has long been recognized as the world's marketing expert, revealed that the notion of marketing is the process by which companies create value for customers and build strong relationships with customers to get the good value from customers in return.

Meanwhile, Hermawan Kertajaya (2002) in M. Liga Suryadana \& Vanny Octavia (2015: 2) states that marketing is a business discipline strategic that directs to the process of creating, offering, and changing value from one initiator to its stakeholders.

Etymologically (Yoeti, 1996 in M. Liga Suryadana \& Vanny Octavia, 2015: 30) said the term tourism itself comes from the Sanskrit language which has the same meaning as tour, which means going round from one place to another. It is based on the idea that the word "tourism (pariwisata)" consists of two syllables, namely "Pari" and "Wisata". Pari, means many, many times, circling, complete, while Tourism, means travel, traveling.

The world tourism organization, UNWTO, defines tourism as the activity of a person's travel and stay outside of their residence and environment for not more than one consecutive year for travel, business, or other purposes without working in the place they visit. According to Hunzieker and Krapf in Soekadijo (2000: 12) in M.Liga Suryadana \& Vanny Octavia (2015: 30), tourism can be defined as a whole network and symptoms related to the stay of strangers in a place, provided that they do not live there for an important job that provides permanent or temporary benefits.

According to Wahab (1992), in the book Tourism Marketing (2017: 2), tourism contains three elements, namely: Human, namely element as the actor of tourism activities; place, namely the physical element which is actually covered by the activity itself; and time, namely the element of the tempo spent on the trip and while staying at the destination. So the definition of tourism 
The Potential Of Dki Jakarta Tourism Object Development Case Study In Pancasila Sakti Monument In Lubang Buaya Jakarta

Rahmawati, Maulina, Widyawan, \& Widyastuti

is one of the new industries capable of rapidly increasing economic growth in terms of employment opportunities, income, living standard and in terms of activating other production sectors in tourist-receiving countries. Meanwhile, according to Spillane (1993), in a tourism marketing book (2017: 2), tourism is a service.

Based on the Indonesian Dictionary, potential is an ability that has the possibility to be developed, strength, ability to power. Tourism contains the potential to be developed into tourism. So to find the potential for tourism in an area, one must give guidance to what tourists are looking for. Potential is something that must be considered and looked at further, it is intended so that all the advantages and potential can be developed and maximized perfectly. Of course all of this cannot be separated from the roles of all related parties, either directly or indirectly. The potential the area and tourism are two things that are closely related, both of which can move forward to develop the regional economy.

The definition of tourism potential according to Mariotti in Yoeti (1983: 160-162) is everything that is in a tourist destination, and is an attraction for people to come or visit the place. Sukardi (1998: 67) also expresses the same definition of tourism potential as everything that a tourist attraction has and is useful for developing the tourism industry in the area.

So, the meaning of tourism potential is something that can be developed into an attraction for a tourist attraction. In this research, the potential is divided into three types, namely: Natural Potential, Cultural Potential and Human Potential.

What is meant by natural potential is the condition and type of flora and fauna of an area, the landscape of an area. For example, beaches, forests, etc. (the physical condition of an area). The advantages and uniqueness possessed by nature, if it is developed with attention to the condition of the surrounding environment, will undoubtedly attract tourists to visit these objects.

What is meant by cultural potential is all creations, tastes and human intentions in the form of customs, handicrafts, arts, ancestral heritage in the form of buildings, monuments, etc. Humans also have the potential that can be used as a tourist attraction, through dance performances and cultural arts performances of an area.

Objects and tourism objects are formations or related activities and facilities, which can attract tourists or visitors to get to certain areas or places (Happy Marpaung, 2002: 78). Tourism object is anything that becomes a tourism objective, tourism object is very closely related to tourism, in an area which is a tourism object must have uniqueness, which becomes the main objective of visiting these areas. The uniqueness of the culture are local culture, flora and fauna, technological progress, spiritual elements, and others.

An object that has an interesting nature is definitely exploited and explored in such a way, so that it can provide maximum income and profit. One thing that must be remembered is that a cultural object cannot provide income and profit, without maximizing it. It is necessary to plan and effort systematically in developing a tourism object, so that we have a variety of tours for tourists to visit.

So, according to the author, what is meant by tourism potential is something that can be developed from a tourism object. Development is defined as an attempt to point to a better, wider or increased direction. Meanwhile, tourism development can be interpreted as an effort to provide or improve the facilities and services needed by the community. 
The Potential Of Dki Jakarta Tourism Object Development Case Study In Pancasila Sakti Monument In Lubang Buaya Jakarta

Rahmawati, Maulina, Widyawan, \& Widyastuti

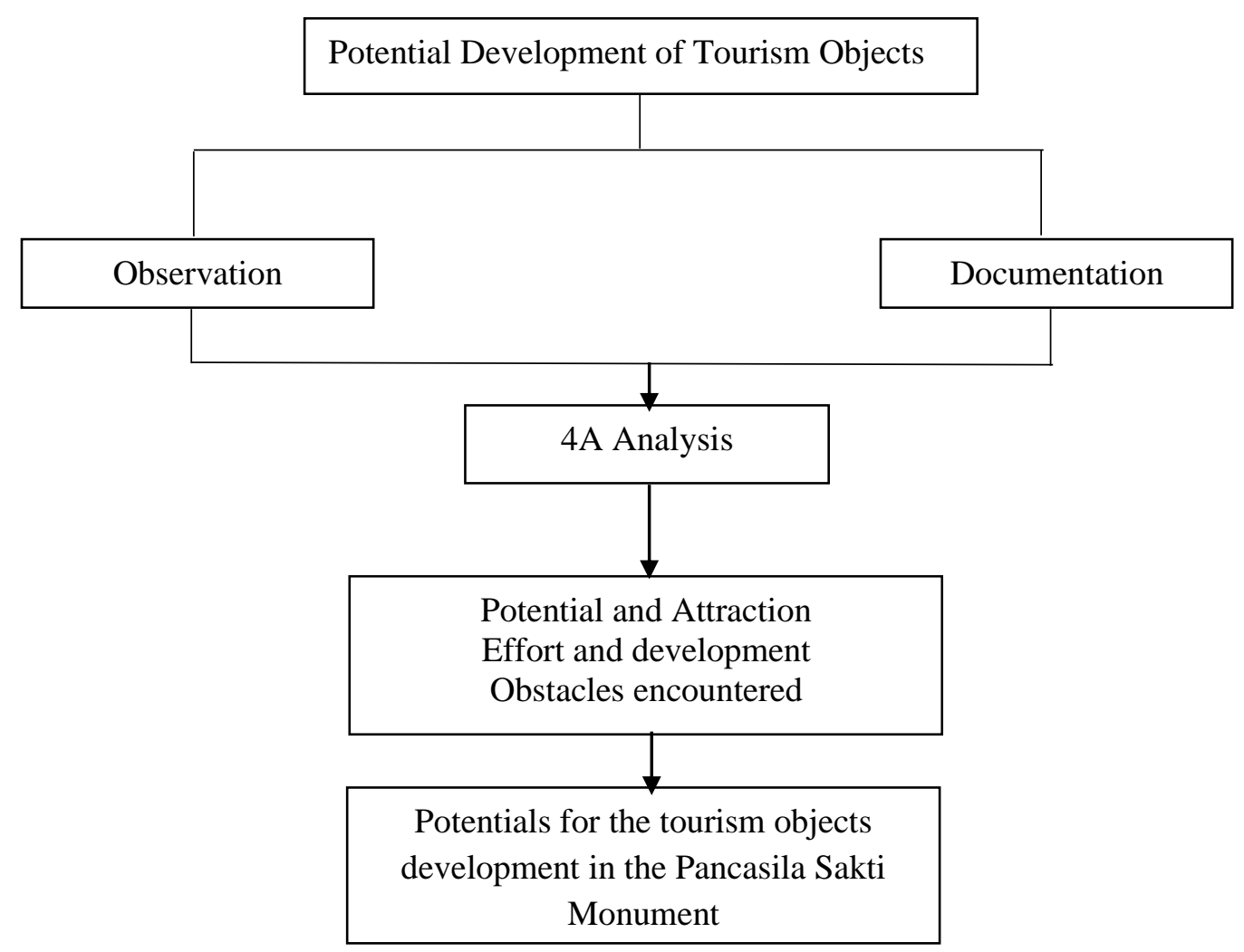

Figure 1. Analysis framework

\section{METHODS}

This research is a type of qualitative descriptive research, namely a study that does not carry out calculations and the research procedure that produces descriptive data in the form of written or spoken words from people and observable behavior (Sugiyono, 2010: 67).

This study used a descriptive qualitative research method, where the researcher describes and explains the situations and conditions that occur after the researcher conducts observations and interviews related to the potential development of the Tourism Object in Pancasila Sakti Monument in Lubang Buaya for the information related to the research. In this study, the researcher is the key instrument.

The research method used by the author is describing the situation that is systematically researched and carried out after obtaining data from observations, interviews, literature studies which are then presented descriptively. The data analysis method used is descriptive analysis method.

\section{RESULTS AND DISCUSSION}

The Potential Development of Tourism Objective in Pancasila Sakti Monument in Lubang Buaya.

Everything that is interesting and worth visiting and seeing the potential that exists in these objects, the meaning of potential according to the Indonesian Dictionary is the ability, power, strength, ability that has the possibility to be developed. The development potential is divided into 3 (three), namely: (1) Potential and Attractiveness in Pancasila Sakti Monument in Lubang 
The Potential Of Dki Jakarta Tourism Object Development Case Study In Pancasila Sakti Monument In Lubang Buaya Jakarta

Rahmawati, Maulina, Widyawan, \& Widyastuti

Buaya ; (2) Potential Development in Pancasila Sakti Monument in Lubang Buaya based on 4A Analysis; and (3) Potential Development based on Revitalization in Pancasila Sakti Monument in Lubang Buaya

\section{Efforts or Solutions For Developing the Tourism Object of Pancasila Sakti Monument in} Lubang Buaya

Various efforts have been made by related parties regarding the development of the Monument Tourism Object. According to the results of interviews with informants, the efforts that have been made are revitalizing the gate, the river near the location of the monument, the parking area and culinary center.

In building and developing a tourism object, it must be designed according to its potential attraction. A tourism development can be said to be successful if the government together with all components take the role active in developing the Indonesian tourism sector, especially in the tourism object of the Pancasila Sakti Monument area.

\section{Constraints in the Development of the Tourism Object of the Pancasila Sakti Monument}

If you look closely, besides the potential that exists in tourist objects, there are also a number of things that become obstacles that need to be fixed and removed in order to achieve the potential development of the Pancasila Sakti Monument in Jakarta. From the results of interviews and observations of the author, the obstacles faced by the Pancasila Sakti Monument for development are: (1) Nearly death of the Spirit of Area (Like a body that is about to be abandoned by its soul). The area which is located on the out of Jakarta, makes people reluctant to travel; (2) The existence of the Pancasila Sakti Monument has not been optimal as an economic center because of the lack of public awareness in supporting these tourism conservation activities; and (3) Creepy impression makes tourists reluctant to visit.

\section{CONCLUSION}

The Pancasila Sakti Monument in Lubang Buaya is as a historical tourism object that is unique and beautiful. Many potentials play a role in supporting the development of tourism objects in the Monument Area, such as historical buildings, locations, accessibility and various other tourist corners that are offered in the Pancasila Sakti Monument Area.

The drawback of these tourism objects is that there has been no renewal in some tourist sites that have been made more attractive and there is a lack of public awareness of these tours which are actually full of knowledge. Apart from that, the prospects or potentials of these tourism objects provide positive benefits to the community around the Pancasila Sakti Monument.

From the results of this research, it makes us aware about the importance of preserving cultural assets, so that they can be developed. Based on the research results, it is very necessary to collaborate between the community, government and tourism object managers to develop this tourism object in the future, especially the development of various sectors in Pancasila Sakti Monument Area.

\section{REFERENCES}

Anggara, Sahya. (2012). Ilmu Administrasi Negara. Bandung: Pustaka Setia. Fahmi, Irham. (2015). Pengantar Ilmu Administrasi. Bandung: Alfabeta. 
The Potential Of Dki Jakarta Tourism Object Development Case Study In Pancasila Sakti Monument In Lubang Buaya Jakarta

Rahmawati, Maulina, Widyawan, \& Widyastuti

Irawan, Koko. (2010). Potensi Objek Wisata Air Terjun Serdang Sebagai Daya Tarik Wisata Di Kabupaten Labuban Batu Utara. Kertas Karya. Program Pendidikan Non Gelar Pariwisata. Universitas Sumatera Utara.

Kotler, dan Keller. (2012). Manajemen Pemasaran. Edisi 12. Jakarta: Erlangga.

Kusumaningrum, Dian. (2009). Persepsi Wisatawan Nusantara Terbadap Daya Tarik Wisata Di Kota Palembang. Tesis PS. Magister Kajian Pariwisata. Universitas Gadjah Mada.

Lupiyoadi, Rambat. (2013). Manajemen Pemasaran Jasa berbasis Kompetensi. Edisi Ketiga. Jakarta: Salemba Empat.

Marpaung, Happy. (2002). Pengetahuan Kepariwisataan. Bandung: Alfabeta.

Masly, Dini. (2017). Potensi Daya Tarik Wisata Nagari Tuo Pariangan sebagai Kawasan Desa Wisata Pariangan Kab. Tanah Datar, Sumatera Barat. https://media.neliti.com/media/publications/206493-potensi-daya-tarik-wisata-nagarituo-par.pdf Diakses 30 Maret 2018.

Nurdianti, Asma. (2013). Potensi Pengembangan Wisata Alam di Habitat Maleo (Macrocephalon Maleo) Taman Nasional Lore Lindu Bidang Pengelolaan Wilayah (BPW) I Saluki Kec. Gumbasa Kab. Sigi. http://jurnal.untad.ac.id/jurnal/index.php/WartaRimba/article/download/1945/ Diakses 29 Maret 2018.

Pemerintah Indonesia. 1969. Instruksi Presiden RI No. 9 Tahun 1969.

Rai Utama, I Gusti Bagus. (2017). Pemasaran Pariwisata. Yogyakarta: CV. Andi Offset.

Sanesta, Aldian. 2015. Strategi Pengembangan Kepariwisataan di Kota Bukit Tinggi. JOM FISIP Universitas Riau Vol.1, No.2

Sendarmayanti. (2016). Manajemen Strategi. Edisi kedua. Bandung: PT. Refika Aditama.

Sugiyono. (2010). Metode Penelitian Kuantitatif Kualitatif dan R \& D. Bandung: Alfabeta.

Sugiyono. (2012). Manajemen Penelitian Kualitatif, kuantitatif dan R \& D. Bandung: Alfabeta.

Sugiyono. (2014). Manajemen Penelitian Kualitatif, Kuantitatif dan R \& D. Cetakan 21. Bandung: Alfabeta.

Sukardi, Nyoman. (1998). Pengantar Pariwisata. STP Nusa-Dua Bali.

Suryadana, Mohamad Liga, dkk. (2015). Pengantar Pemasaran Pariwisata. Bandung: Alfabeta.

Usman, Husaini dan Akbar, Purnomo Setiady. (2011). Metodologi Penelitian Sosial. Jakarta: Bumi Aksara.

Yoeti, Oka A. (1983). Pengantar Ilmu Pariwisata. Bandung: Angkasa. 